up in Indiana and attended Indiana University, receiving his AB in 1925 and $A M$ in 1926, both in physics. In addition to his academic pursuits, he participated in varsity baseball and tennis. He received his $\mathrm{PhD}$ in physics from the University of Wisconsin in 1931.

He was an instructor in physics at the University of Wisconsin from 1930 to 1937. During his graduate work and until 1934, he did research in solid state physics, specialising in the surface structure of metals. In 1934 he switched to nuclear physics, which thereafter remained his principal field.

Following one year as a Lalor Fellow in physical chemistry at the Massachusetts Institute of Technology, Haworth, in 1938, joined the physics department of the University of Illinois. His association with Illinois continued until 1947 except for five years of war-time leave at MIT.

Dr Haworth was a member of the board of directors of Oak Ridge Associated Universities (ORAU) from 1959 to 1961, and again from 1971 to February 1978, when he was elected director emeritus-the first time ORAU had made such an appointment.

$\mathrm{He}$ was a member of the National Academy of Sciences, the American Philosophical Society, Phi Beta Kappa and Sigma Xi. He was a fellow of the American Physical Society, the New York Academy of Sciences, the American Academy of Arts and Sciences, and the American Nuclear Society (member of board of directors, 1955-60; president, 1957-58).

For his work during World War II, Haworth received the President's Certificate of Merit. A mesa in the Antarctic and an asteroid have been named in his honour. He was the recipient of many honorary degrees.

The name of Haworth is synonymous with meticulous care for the work at hand. His traits of objectivity, attention to detail and sensitivity to the problems of others influenced all who worked wath him, and we are the better for it. The institutions with which he worked have been left with a Haworth heritage, and they are the better for it.

Gerald F. Tape

\section{W. R. Aykroyd}

Dr Wallace Ruddel.l. Aykroyd, CBE, who died on 7 February 1979, aged 79, was a nutritionist of international reknown since the early days of his career. His ability for meticulous work and great clarity of thought were soon recognised and his powers of organisation and administration left their mark in the many posts of distinction he held, particularly as the first Director of the Nutrition Division of the Food and Agriculture Organisation of the United
Nations from 1946 until 1960. His capacity to marshal facts and produce scientific reports in stylish and fluent prose made his publications important and influential in the fields of nutrition, public health and agriculture.

Graduating in medicine at Trinity College, Dublin, in 1924, where he was awarded the Vice-Chancellor's prize in English prose, he was appointed House Surgeon at the General Hospital, St John's, Newfoundland. He became interested in the deficiency diseases of the poorer fishermen and published an article on vitamin A deficiency in 1928 and a comprehensive report, 'Beriberi and other Deficiency Diseases in Newfoundland and Labrador', in the Journal of Hygiene in 1930. This 30page report illustrates well the qualities which were to become the hallmark of his work-a broad approach, clear presentation of facts and a deep compassion for the unfortunate victims of malnutrition. He recognised that the diseases found were not due to deficiencies of single nutrients but multiple deficiencies due to poverty and a monotonous winter diet. His findings were used, and confirmed, by a team, which included B. S. Platt and W. H. Sebrell, conducting a medical survey of nutrition in Newfoundland some fifteen years later.

After his appointment to the Health Organisation of the League of Nations in 1931 he pursued his research into the link between malnutrition and poverty at a time of international recession and severe unemployment. His report, Diet in Relation to Small Incomes, published by the League of Nations in 1933, included a scholarly discussion on adequate dietary standards and satisfactory nutrition at low cost and his critical appraisal and distrust for the high protein allowances recommended was well in advance of his time and makes salutary reading today. The report is a valuable historical record of the time, containing studies of working class diet and expenditure on food in Germany, England and the USA.

The Health Organisation of the League of Nations decided, in 1934, that a general report on nutrition was needed after some ten years of studies of nutrition in the field of public health. Dr Aykroyd and Dr Etienne Burnet were asked to undertake this by making a series of enquiries in different countries and to report on nutritional status, research and policies. Their publication, Nutrition and Public Health, printed by the League of Nations in 1935, was an important statement of the current nutrition situation and was used extensively by international committees in public health and agriculture as well as the International Labour Office. Following this report the Health Organisa- tion set up a Technical Commission for the Study of Nutrition which convened meetings of groups of experts who then produced reports (a procedure continued by FAO and WHO). The first report, The Physiological Bases of Nutrition (1936), relied heavily on the findings of the Aykroyd and Burnet report.

Following his appointment as Director of the Nutrition Research Laboratories in Coonoor, India, in 1935, Dr Aykroyd continued his work as an expert for the Technical Commission including research on the effect on nutrients of the milling of cereals and the influence of climate on food requirements. His work in India greatly enhanced the reputation of nutrition research in that country and the world famous Indian National Institute of Nutrition at Hyderabad was the result of his efforts. To this day, revised editions of The Nutritive Value of Indian Foods and the Planning of Satisfactory Diets retains his name as principal author in recognition of his original concepts for the work.

During his period at FAO from 1946 Dr Aykroyd's leadership gave the Nutrition Division a fine start and the reports of the Expert Committees (some jointly with WHO), which owed a lot to his guidance and editing, are consulted throughout the world. After his retirement from FAO, in 1960, he joined Professor B. S. Platt at the Department of Human Nutrition, London School of Hygiene and Tropical Medicine, where, as Senior Lecturer, he helped to set up regular courses which led to the present MSc in Human Nutrition, attended by graduates from all over the world. He wrote several books at this time including Food for Man and The Conquest of Deficiency Diseases which explained nutritional problems in terms understandable and interesting for the untrained reader. During his work as co-author of the FAO Studies, Legumes in Human Nutrition and Wheat in Human Nutrition he was able to indulge in his love of history as well as use his powers of marshalling a mass of facts into lucid and readable prose.

This interest in history, which had led to the writing in 1935 of Three Philosophers, one of whom had been his great hero, Lavoisier, was also evident in his book Sweet Malefactor: Sugar, Slavery and Society.

During his active retirement he carried on with nutrition consultancy work for WHO and OXFAM and found time to write The Conquest of Famine. A fitting tribute was made when this received the first award of a joint book award scheme of the British, Swedish and American Nutrition Foundations.

Joyce Doughty 